\title{
Geoquímica e estrutura dos ortognaisses das ilhas do Balneário Barra do Sul e de São Francisco do Sul, litoral norte do Estado de Santa Catarina Geochemistry and structure of the orthogneisses from islands of Barra do Sul and São Francisco, northern coast of Santa Catarina State
}

\author{
Michelangelo Tissi Baldin¹, Carlos Eduardo de Mesquita Barros², Leonardo Fadel Cury² \\ ${ }^{1}$ Programa de Pós-graduação em Geologia, Universidade Federal do Paraná - UFPR, Departamento de Geologia, UFPR, \\ Centro Politécnico, Jardim das Américas, CEP 81531-980, Curitiba, PR, BR (miche_georock@yahoo.com.br) \\ ${ }^{2}$ Departamento de Geologia, Universidade Federal do Paraná - UFPR. Laboratório de Análises de Minerais e Rochas - \\ LAMIR (cadubarros@ufpr.br; leonardo.fadel.cury@gmail.com)
}

Recebido em 01 de abril de 2015; aceito em 10 de fevereiro de 2017

\begin{abstract}
Resumo
As rochas das ilhas do Balneário Barra do Sul afloram na porção nordeste do Estado de Santa Catarina e estão distribuídas ao longo de uma faixa alongada segundo a direção geral N15-20E. As rochas estudadas compreendem a região norte do Cinturão Dom Feliciano, situam-se a leste da Microplaca Luís Alves e são enquadradas no Complexo São Francisco do Sul (Terreno Paranaguá). Esta pesquisa foi desenvolvida por meio de cartografia detalhada, petrografia, geoquímica e análise estrutural. Nas ilhas dos Remédios e Feia afloram granodiorito e monzogranitomilonitizado de aspecto gnáissico. Duas fases de cisalhamento dúctil foram identificadas: a primeira associada à tectônica de cavalgamento e a segundade natureza transcorrente sinistral. Essas rochas têm assinatura cálcio-alcalina e álcali-cálcica, com termos metaluminosos a fracamente peraluminosos, semelhantes aos granitos do tipo I-Cordilheirano, gerados em arco magmático continental.
\end{abstract}

Palavras-chave: Terreno Paranaguá; Granitos do Tipo I; Assinatura Cálcio-alcalina.

Abstract

The rocks of the islands of Balneário Barra do Sul outcrop in northern coast of Santa Catarina state and are distributed along the N15-20E direction. These rocks comprise the northern Dom Feliciano Belt, located to the east of the Luís Alves Microplate and belong to the San Francisco South Complex (Paranaguá Terrane). The research was developed by means ofdetailed cartography, petrography, geochemistry and structural analysis. The Remédios and Feia islands are composed of granodiorite and monzogranitemylonites having gneissic aspect. These rocks underwent two phases of ductile deformation: the first is related to thrusting and the second is related to sinistral strike-slip tectonics. These rocks are arecalc-alkalic and alkali-calcic, and metaluminous to weakly peraluminous. They show characteristics of I-type cordilleran granitewhose origin is attributed to continental magmatic arc.

Keywords: Paranaguá Terrane; I Type Granites; Calc-alkaline Signature. 


\section{INTRODUÇÃO}

As ilhas dos Remédios, Feia e das Araras situam-se no litoral norte do Estado de Santa Catarina, em frente ao município do Balneário Barra do Sul (Figura 1). A posição estratigráfica controversa das rochas dessas ilhas, somada às excelentes exposições de rochas, estimulou a realização deste trabalho.

Inicialmente, as ilhas do Balneário de Barra do Sul foram cartografadas como sendo constituídas por terraços e sedimentos marinhos terciários/quaternários (DNPM, 1986). Posteriormente, suas rochas foram atribuídas ao Complexo São Francisco do Sul por Iglesias et al. (2011).

$\mathrm{O}$ acesso ao município do Balneário Barra do Sul

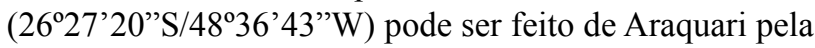
BR-280 em direção a São Francisco do Sul e, em seguida, pela rodovia SC-415. Para se chegar às ilhas utiliza-se um barco pequeno a partir do Balneário Barra do Sul. Nas ilhas, os afloramentos são quase contínuos ao longo das suas margens, seja sob a forma de costões ou de blocos.

Os principais objetivos deste trabalho foram compreender a evolução estrutural e metamórfica das rochas da região do Balneário Barra do Sul, contribuir para o entendimento do arranjo estrutural que permitiu a colagem do Terreno Paranaguá com a Microplaca Luís Alves e discutir os mecanismos de deformação/recristalização na escala microscópica. Pretende-se investigar a natureza dosprotólitos das rochas metamórficas, contribuir para o posicionamento estratigráfico das localizadas nas ilhas do Balneário Barra do Sul, além de compará-las às da ilha de São Francisco do Sul. Também são apresentados dados geoquímicos das rochas das ilhas dos Remédios e Feia, os quais são comparados com os das pertencentes à Ilha de São Francisco do Sul.

\section{GEOLOGIA REGIONAL}

De acordo com Basei et al. (2000), o Complexo MáficoUltramáficoPiên define o limite norte-noroeste da Microplaca Luís Alves com a Microplaca Curitiba, ao passo que o limite sul é marcado pelas rochas da Bacia do Itajaí. A leste, o contato é, em parte, com o Terreno Paranaguá por falhas de cavalgamento e transcorrentes e, pela costa brasileira (Siga Junior et al., 1993). A porção oeste limita-se pela Bacia do Paraná (Figura 2).

A Microplaca Luís Alves é constituída por rochas do Complexo Máfico-Ultramáficode Barra Velha e do Complexo Granulítico de Santa Catarina (Hartmann et al., 1979; Basei et al., 1998), e consiste em domínios geotectônicos proterozoicos.

$\mathrm{Na}$ Microplaca Luís Alves predominam ortognaisses sobre migmatitos, granitos e rochasultramáficas (Basei et al.,
1998). O bandamento dos gnaisses tem direção NW e sua origem teria ocorrido em condições de alto grau metamórfico (Basei et al., 1992).

Hartmann et al. (2000) sugeriram quatro eventos metamórficos, com base em datações U-Pb (SHRIMP) em cristais de zircão. A fase $M_{1}$ teve auge metamórfico em 2,68 Ga, na fácies granulito; a $\mathrm{M}_{2}$, de fácies anfibolito, teria ocorrido há $2,1 \mathrm{Ga}$; a $\mathrm{M}_{3}$, também de fácies granulito, há $2,17 \mathrm{Ga}$; e a $\mathrm{M}_{4}$, de baixo grau, manifesta-se em zonas de cisalhamento.

O Complexo Ultramáfico de Barra Velha (Minioli, 1972; Fornari, 1998) engloba gabro, gabronorito, anfibolito, piroxenito, noritoe magnetitito, que cortam granulitosfélsicos do Complexo Granulítico de Santa Catarina.

De acordo com Figueiredo et al. (1991), os gnaisses granulíticos têm composição cálcio-alcalina. Seus padrões de elementos terras raras são fracionados e apresentam teores baixos de elementos incompatíveis. Esses autores sugeriram que os protólitos se originaram em zona de subducção de arco insular, pela fusão parcial de fontes mantélicas com granada na fase residual.

Datações Rb-Sr (Hartmann et al., 1979; Basei, 1985; Basei et al., 1992; Siga Junior et al., 1993; Siga Junior, 1995) em rocha total forneceram idades em torno de 1,92,0 Ga e 2,3 Ga. Esses estudos propõem a existência de rochas geradas no manto e/ou na crosta inferior, formadas no Arqueano e homogeneizadas no Paleoproterozoico, com idades distribuídas entre 2,2 e 1,9 Ga e baixas razões iniciais ${ }^{87} \mathrm{Sr} /{ }^{86} \mathrm{Sr}(0,702-0,704)$. Datações U-Pb (Basei, 1985; Siga Junior, 1995) em zircão de migmatitos e gnaisses granulíticos mostraram idades entre 2,8 e 2,2 Ga. As idades mais antigas refletiriam a absorção de material ígneo à crosta, e as mais recentes seriam do pico metamórfico de fácies granulito. Segundo Harara (2001), esse pico caracteriza o período de $2060 \pm 6 \mathrm{Ma}$, com heranças em torno de 2,2 - 2,1 Ga, interpretadas como uma fase metamórfica anterior.

As idades K-Ar em biotita, anfibólio e plagioclásio variam de 2100 a $1700 \mathrm{Ma}$ e traduzem o resfriamento dos terrenos granulíticos. Elas podem retratar perdas parciais ou mesmo totais de argônio, pelo envolvimento tectono-termal desses terrenos na evolução brasiliana (Siga Junior et al., 1993).

O Terreno Paranaguá situa-se no sudeste de São Paulo, leste do Paraná e nordeste de Santa Catarina, sob a forma de uma faixa de direção NE-SW de $250 \mathrm{~km}$ de extensão e $30 \mathrm{~km}$ de largura. Ele é formado por gnaisses e migmatitos (Complexo São Francisco do Sul), rochas metassedimentares da Formação Rio das Cobras e granitos das suítes Morro Inglês, Rio do Poço e CanavieirasEstrela (Cury, 2009).

O Complexo São Francisco do Sul é formado por diorito, quartzo monzodiorito, granodiorito, trondhjemito e monzogranito, cujas datações U-Pbem zircão forneceram idade de $2173 \pm 18 \mathrm{Ma}, 626 \pm 25 \mathrm{Ma}$ e $510-490 \mathrm{Ma}$ (Cury, 2009). 


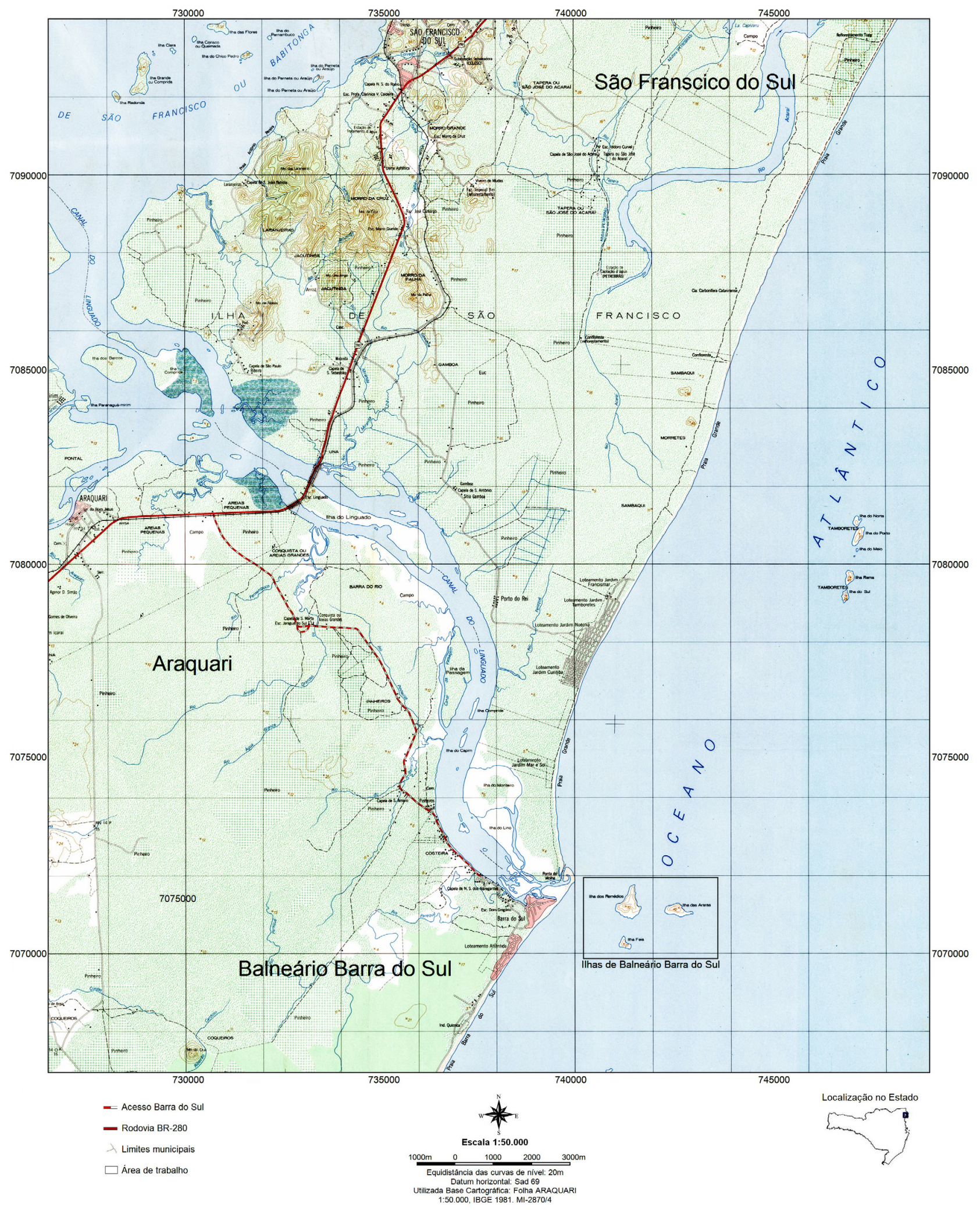

Fonte: IBGE, 1981.

Figura 1. Localização da área de estudo. Coordenadas Universal Transversa de Mercator, banda 22. 
A Formação Rio das Cobras engloba biotita-quartzo xisto, muscovita-quartzo xisto, xistocalciossilicático, granada-silimanita-sericita-quartzo xisto, quartzito, gnaisses granatíferos, mármore e anfibolito. Datações U-Pb em zircão dos gnaisses de alto grau forneceram idades de 1,8 a 2,1 Ga (Cury, 2009).

A Suíte Morro Inglês (Lopes, 1987) é composta por monzogranitos porfiríticos, granodioritos, sienogranitos, tonalitos e dioritos cinza-claro a cinza-escuro, granulação grossa a muito grossa, e com fenocristais de microclínio, plagioclásio e quartzo. A estrutura dessas rochas é maciça ou foliada, e a deformação é incipiente a intensa. São cálcio-alcalinos de alto $\mathrm{K}$ a shoshoníticos, mostram concentrações relativamente altas de $\mathrm{Ba}, \mathrm{Nb}, \mathrm{Zr}, \mathrm{Rb}$, $\mathrm{Sr}$, Th e $\mathrm{K}_{2} \mathrm{O}$ e assinatura indicadora de arco magmático maduro, com fontes modificadas pela contaminação crustal (Cury, 2009).

A Suíte Rio do Poço (Lopes, 1987) compreende leucogranito com duas micas e granito porfirítico com textura rapakivi. O leucogranitotem granulação inequigranular média, estrutura maciça ou foliação de fluxo e é constituído por microclínio, quartzo, plagioclásio, biotita, epidoto, muscovita, allanita, apatita e zircão. O sienogranito e monzogranito porfirítico mostram textura hipidiomórfica a xenomórfica e estrutura maciça, sendo compostos por microclínio, plagioclásio, quartzo, biotita, titanita, apatita, allanita e zircão. Essas rochas graníticas são metaluminosas a peraluminosas e podem ser classificadas como pertencentes ao tipo A (Cury, 2009).

A Suíte Canavieiras-Estrela é formada por quartzo-monzodiorito, leuco-granodiorito, sienogranito e monzogranito, com termos inequigranulares e porfiríticos. Enclaves anfibolíticos estirados e boudinados são descritos nas rochas dessa suíte (Cury, 2009).

Segundo Cury (2009), as idades das suítes Morro Inglês, Rio do Poço e Canavieiras-Estrela estão no intervalo de 600 a $580 \mathrm{Ma}$ e marcam o principal período do magmatismo no Terreno Paranaguá.

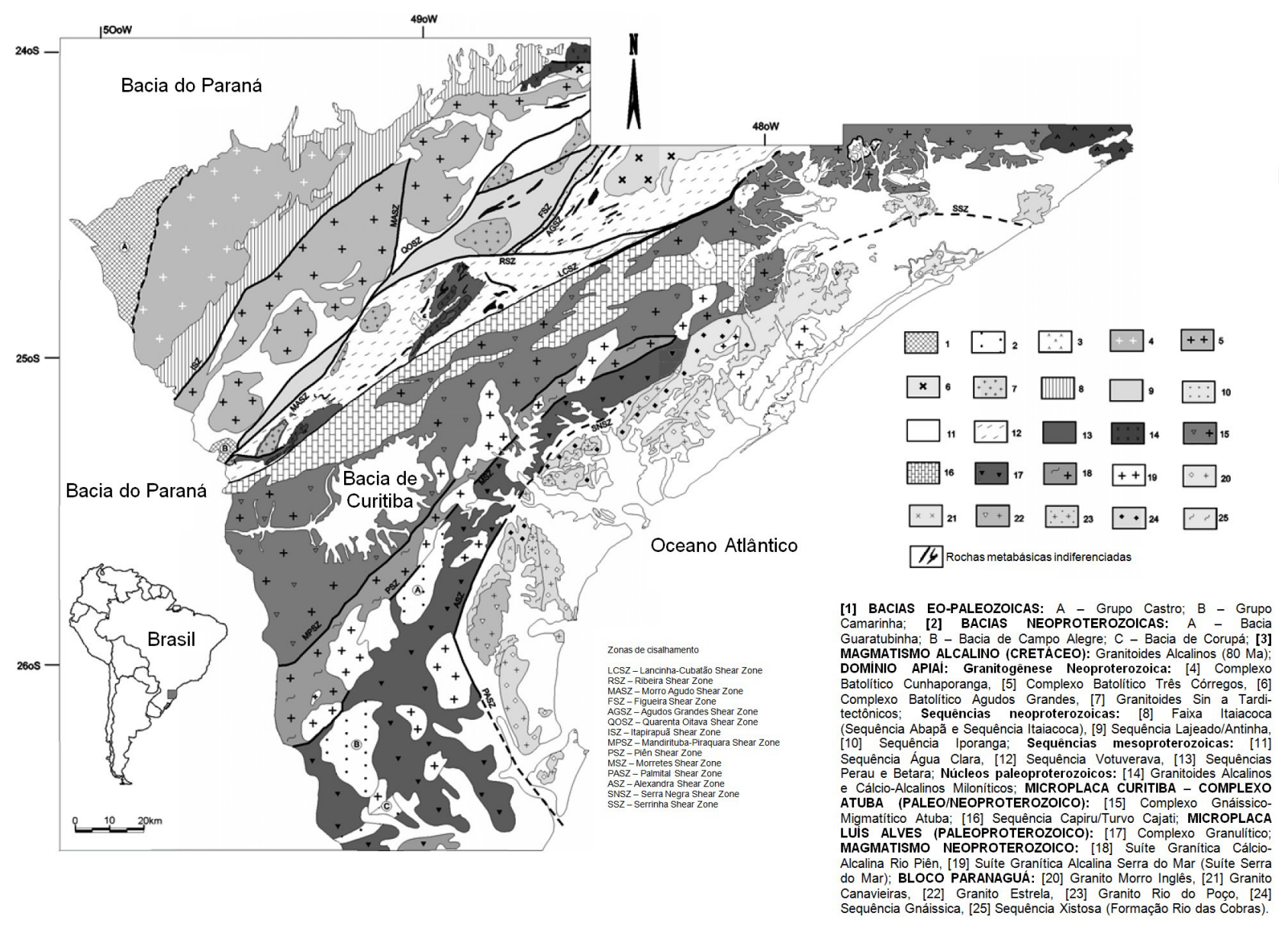

Fonte: adaptado de Cury, 2009.

Figura 2. Esboço geológico do sul do Domínio Apiaí, das microplacas Curitiba e Luís Alves e do Terreno Paranaguá. 


\section{GEOLOGIA DAS ILHAS DO BALNEÁRIO BARRA DO SUL}

Os estudos petrográficos e estruturais das rochas das ilhas do Balneário Barra do Sul foram desenvolvidos principalmente no lado oeste das ilhas, que são compostas por rochas ortognáissicas, pertencentes ao Complexo São Francisco do Sul (Terreno Paranaguá), segundo similaridades petrográficas e estruturais.

A ilha dos Remédios(Figura 3) e a Feia (Figura 4) são constituídas por rochas quartzo-feldspáticas fortemente foliadas com algumas porções relativamentericas em enclaves metaultramáficos, anfibolíticos e gnáissicos.

As rochas quartzo-feldspáticas deformadas apresentam, em escala de afloramento, aspecto gnáissico; entretanto, como será apresentado a seguir, elas foram consideradas como pertencentes à série dos milonitos, de acordo com a classificação de Sibson (1977).

\section{Petrografia}

Nas ilhas do Balneário Barra do Sul ocorrem ortognaisses protomiloníticos (Figura 5A) e miloníticos. Os enclaves estão presentes em diversos pontos das ilhas dos Remédios e Feia e apresentam formas variadas, acompanhando, muitas vezes, a foliação protomilonítica ou milonítica $(\mathrm{Sn})$.

\section{Ortognaissesprotomiloníticos}

Os ortognaisses protomiloníticos ocorrem nas porções sul, sudoeste e norte da ilha dos Remédios e na região oeste da ilha Feia, com ótimas exposições nos costões rochosos, compostos predominantemente por granodioritocinza claro. A textura é inequigranular fina a grossa $(1 \mathrm{~mm}$ a $2 \mathrm{~cm})$. Há um bandamento $(\mathrm{Sn})$ regular, retilíneo a ondulado, de espessura milimétrica a centimétrica $(0,2-2,0 \mathrm{~cm})$, com níveis quartzo-feldspáticosalternados com níveis cinza-escurosricos em minerais máficos. A rocha é formada por quartzo (30\%), oligoclásio (25\%), microclínio (20\%), anfibólio $(15 \%)$, biotita (10\%) e minerais acessórios como opacos, zircão, allanita, titanita e apatita. Os minerais secundários são clorita, sericita, epidoto, carbonato eestilpnomelano. A textura milonítica é definida por porfiroclastos arredondados ou alongadosde microclínio, circundados por níveis irregulares de novos grãos de biotita ou de agregados de novos grãos de quartzo e feldspatos.

Os cristais de quartzo são finos, anédricos granulares, mostram forte orientação preferencial, extinção ondulante, subgrãos, feições do tipo bulging, cristais estirados e novos grãos. Localmente são observados microfraturas em novos grãos. $\mathrm{O}$ arranjo dos agregados de novos grãos é poligonal a inequigranular interlobado, segundo a classificação de Moore (1970).
Os cristais de oligoclásio são anédricos a subédricos prismáticos e finos a grossos. Ocorrem orientados e encontram-se moderadamente a intensamente saussuritizados e sericitizados. A maioria deles tem extinção ondulante. Observam-se, eventualmente, geminação mecânica, curvamento de macla, microfraturas preenchidas por quartzo, sericita e biotita, fraturas fechadas, microfalhas, sobrecrescimento da sericita e dobras em kinksbands.

O microclínioé fino a grosso, anédrico a subédrico e exibe forte orientação preferencial, paralela ao bandamento composicional. Os porfiroclastos são pertíticos e em suas bordas podem haver novos grãos (Figura 5B). Também é possível observar pertitas em chama, extinção ondulante, mirmequitas, microfalhas, fraturas fechadas e fraturas preenchidas por sericita e biotita.

O anfibólio é castanho esverdeado, fino a grosso, anédrico a subédrico e prismático. Pode mostrar orientação preferencial moderada paralelamente ao bandamento composicional. Há extinção ondulante e, mais raramente, microfalhas. A alteração é de fraca a moderada e representada pelos minerais opacos e pela biotita. Microfraturas preenchidas por biotita e óxido de ferro são comuns em cristais de anfibólio.

A cor da biotita varia de castanho-claro a verde-escuro. Trata-se de um mineral que ocorre sob a forma de cristais finos a médios, anédricos a subédricos, fortemente orientados e dispostos em níveis finos anastomosados. Apresenta extinção ondulante, estiramento e kinkbands. Localmente aparece preenchendo fraturas.

Os minerais opacos são finos, subédricos quando primários e anédricos quando secundários. Em geral, são intersticiais ou associam-se ao anfibólio, à titanita e à biotita. Localmente preenchem fraturas em microclínio.

Os cristais de zircão são muito finos, zonados e de hábito euédrico prismático. Não apresentam orientação preferencial e encontram-se dispersos pela rocha. Os limites são curvilíneos e retilíneos.

A allanita é fina, anédrica a subédrica, em geral associada aos cristais de biotita e de anfibólio ou de modo intersticial na matriz. Fraturas discretas e feições de corrosão parcial podem ser observadas na allanita. A apatita é fina, subédrica a euédrica e ocorre de modo intersticial ou sob a forma de inclusão em cristais de quartzo, biotita e oligoclásio.

Os cristais de titanita primária são finos e subédricos, apresentam pouca a moderada orientação preferencial e estão fracamente alterados para óxido de ferro. A titanita secundária, por sua vez, é fina, anédrica a subédrica, não mostra orientação preferencial e forma agregados opacos e associados à biotita e ao anfibólio.

A clorita ocorre em bordas da biotita ou em agregados fibrorradiados associados àsericita e à biotita e, por vezes, de forma intersticial na matriz. 


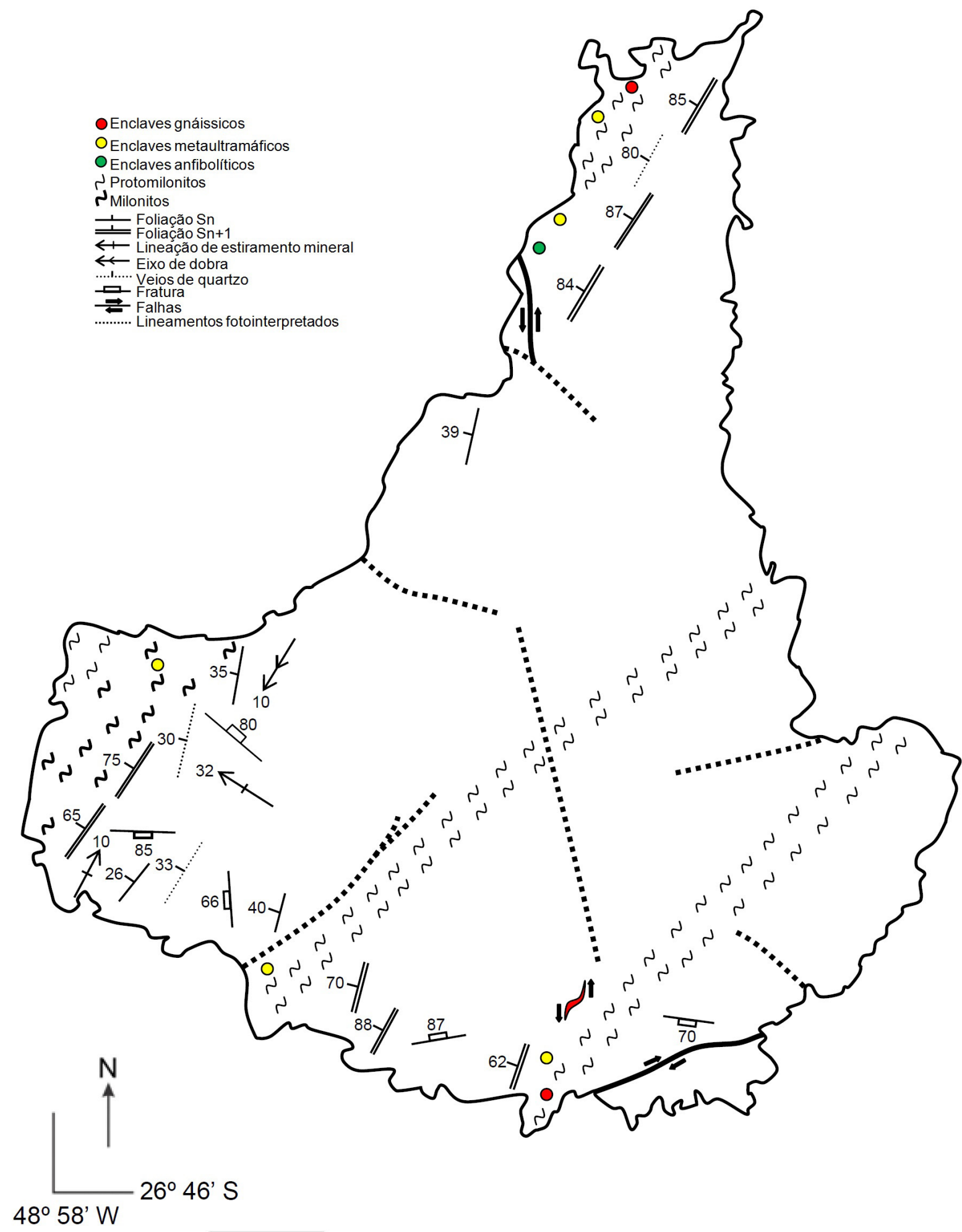

$50 \mathrm{~m}$

Figura 3. Mapa geológico da llha dos Remédios, Balneário Barra do Sul. Coordenadas Universal Transversa de Mercator, banda 22. 


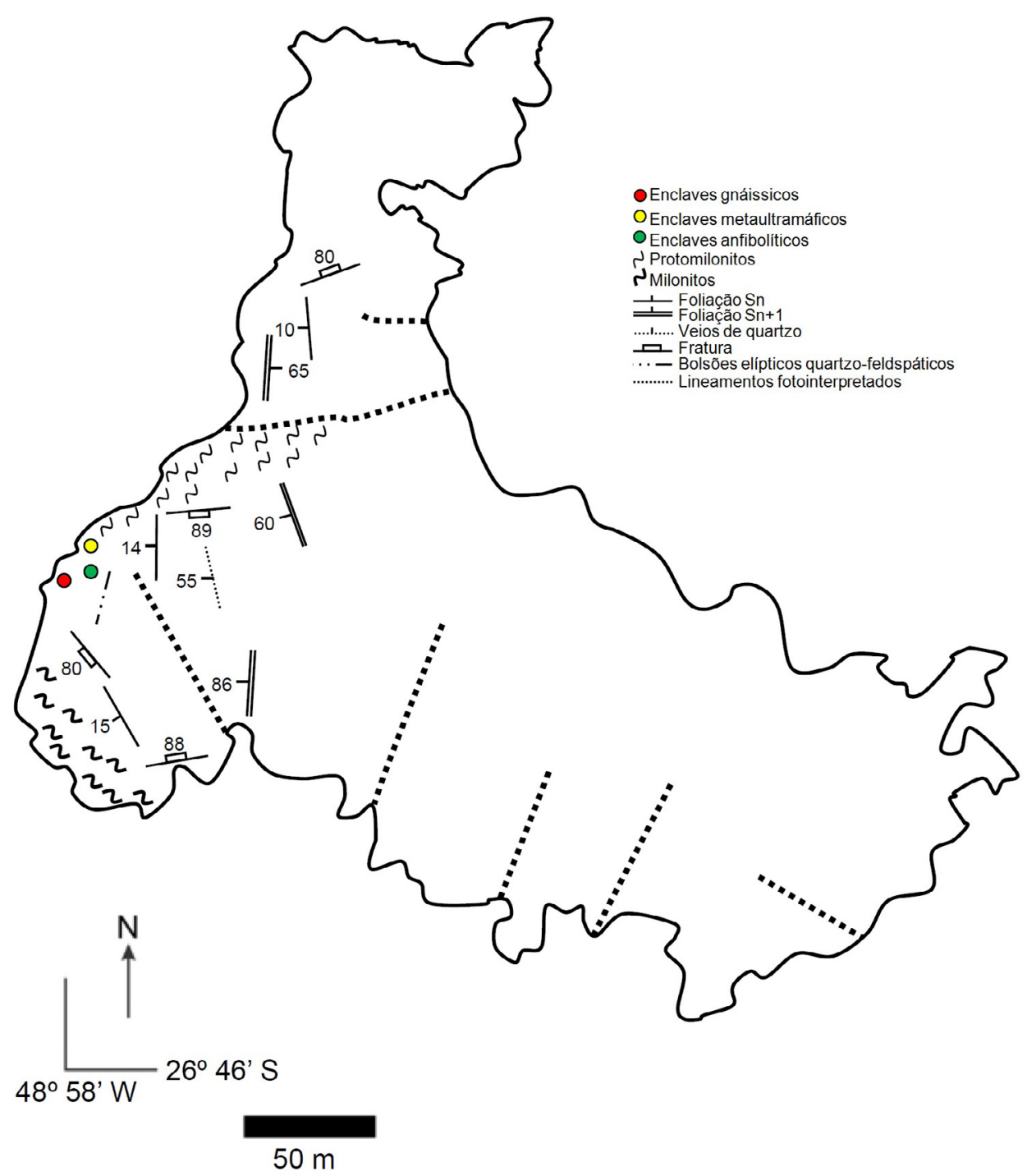

Figura 4. Mapa geológico da Ilha Feia, no Balneário Barra do Sul. Coordenadas Universal Transversa de Mercator, banda 22.
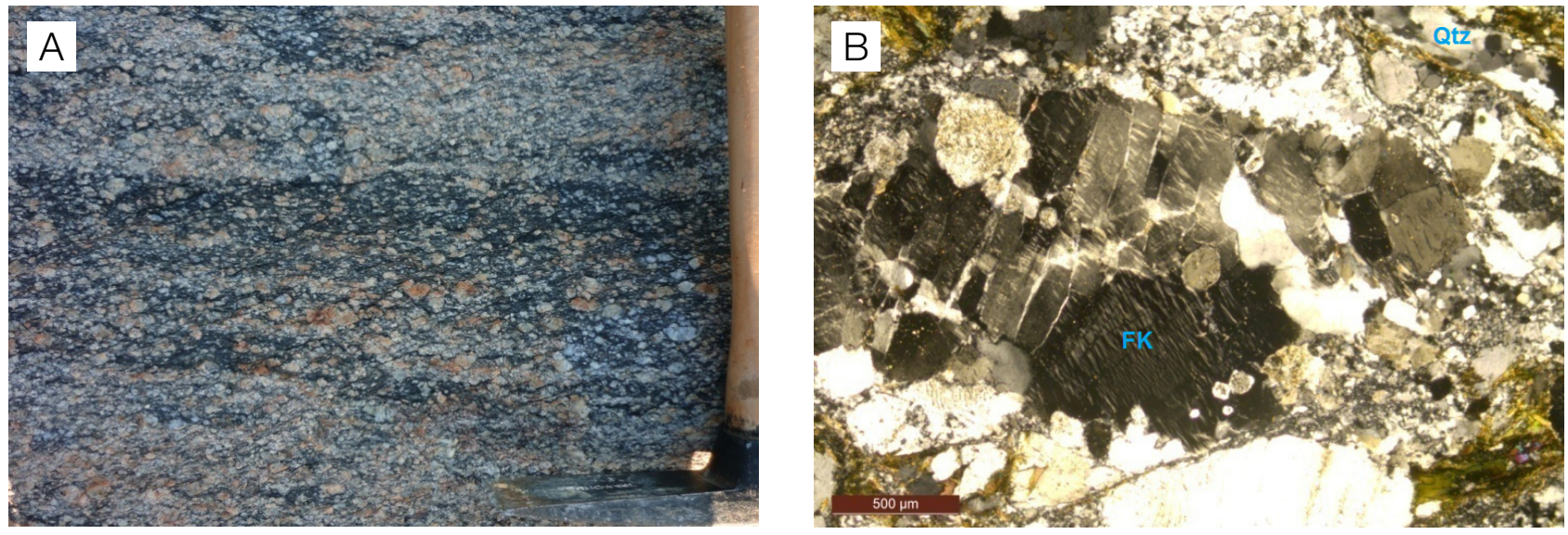

Figura 5. (A) Aspecto mesoscópico do gnaisse protomilonítico; (B) fotomicrografia (luz com polarizadores cruzados) de gnaisse milonítico mostrando porfiroclasto de microclínio circundado por novos grãos de quartzo e feldspatos. 
Os cristais de sericita, epidoto, carbonato e calcita são finos, anédricos e desenvolvem-se sobre plagioclásio como produtos da saussuritização.

\section{Ortognaissesmiloníticos}

Nas partes sudoeste e oeste da ilha dos Remédios e na porção sudoeste da ilha Feia há gnaisses miloníticos de cor cinza-claro (Figura 6A), inequigranulares com cristais em torno de $1,0 \mathrm{~mm}$ a $1,5 \mathrm{~cm}$. São caracterizados por um bandamento composicional $(\mathrm{Sn})$ milimétrico a centimétrico $(0,1-2,5 \mathrm{~cm})$, marcado pela intercalação de níveis esbranquiçados quartzo-feldspáticos e níveis cinza-escuros compostos por minerais máficos. A geometria é planar paralela a ondulada e contínua. A rocha tem composição granodiorítica e é formada por quartzo (35\%), oligoclásio $(25 \%)$, microclínio $(20 \%)$, biotita $(15 \%)$ e sericita $(5 \%)$. A textura milonítica é marcada por níveis irregulares de neoblastos de quartzo, feldspato e biotita, que contornam porfiroclastos aleatórios de feldspatos.

Os cristais de quartzo são finos, anédricos e estão fortemente orientados. O quartzo constitui agregados de subgrãos e novos grãos levemente alongados, dispostos em domínios anastomosados que circundam porfiroclastos de feldspatos. Extinção ondulante e microfraturas ocorrem de modo subordinado.

Os cristais de oligoclásio são finos a médios, anédricos a subédricos e têm moderada orientação preferencial,extinção ondulante, saussuritização moderada e fraturas preenchidas por quartzo.

Os cristais de microclínio são finos a grossos, anédricos a subédricos e mostram forte orientação preferencial, extinção ondulante, subgrãos e novos grãos. Porfiroclastostêm forma amendoada, pertitas em chama,mirmequitas,microfalhas, fraturas fechadas e fraturas com quartzo, biotita e sericita.
Os cristais de biotita são finos, subédricos a anédricos, mostram moderada orientação preferencial, extinção ondulante e kinkbands. Por vezes,estão dispostos em níveis anastomosados que contornamporfiroclastos de feldspatos (Figura 6B).

Os cristais de sericita são muito finos, subédricos, fortemente orientados e dispostos de modo intersticial, formando níveis anastomosados junto à biotita. A sericita resulta da alteração do oligoclásio.

A allanita é fina, anédrica a subédrica e não mostra orientação preferencial. Há raras fraturas, por vezes inclusões de minerais opacos e alteração incipiente para óxido de ferro. A apatita, por sua vez, é fina, anédrica e sua orientação preferencial é fraca.Os cristais de zircão são muito finos, zonados e com aspecto prismático.

Os cristais de opacos primários são finos, subédricos, têm fraca orientação preferencial e associam-se à titanita e à biotita, enquanto os secundários são anédricos, finos, não têm orientação preferencial e desenvolvem-se ao redor da biotita.

Já os cristais de titanita primária são finos, anédricos a subédricos, não têm orientação preferenciale associam-se aos níveis de biotita. E os cristais de titanita secundária são finos, anédricos e formam pequenos agregados granulares sem orientação preferencial.

Os cristais de epidoto são muito finos, anédricos, sem orientação preferencial e ocorrem no interior do oligoclásiosaussuritizado.

\section{Enclaves anfibolíticos}

Essas rochas estão presentes em diversos pontos das ilhas dos Remédios e Feia, apresentam formas alongadas, angulosas, arredondadas (Figura 7A), sigmoidais e interdigitadas, acompanhando muitas vezes a foliação Sn. Apresentam corcinza-escuro e textura inequigranular, sendo compostas
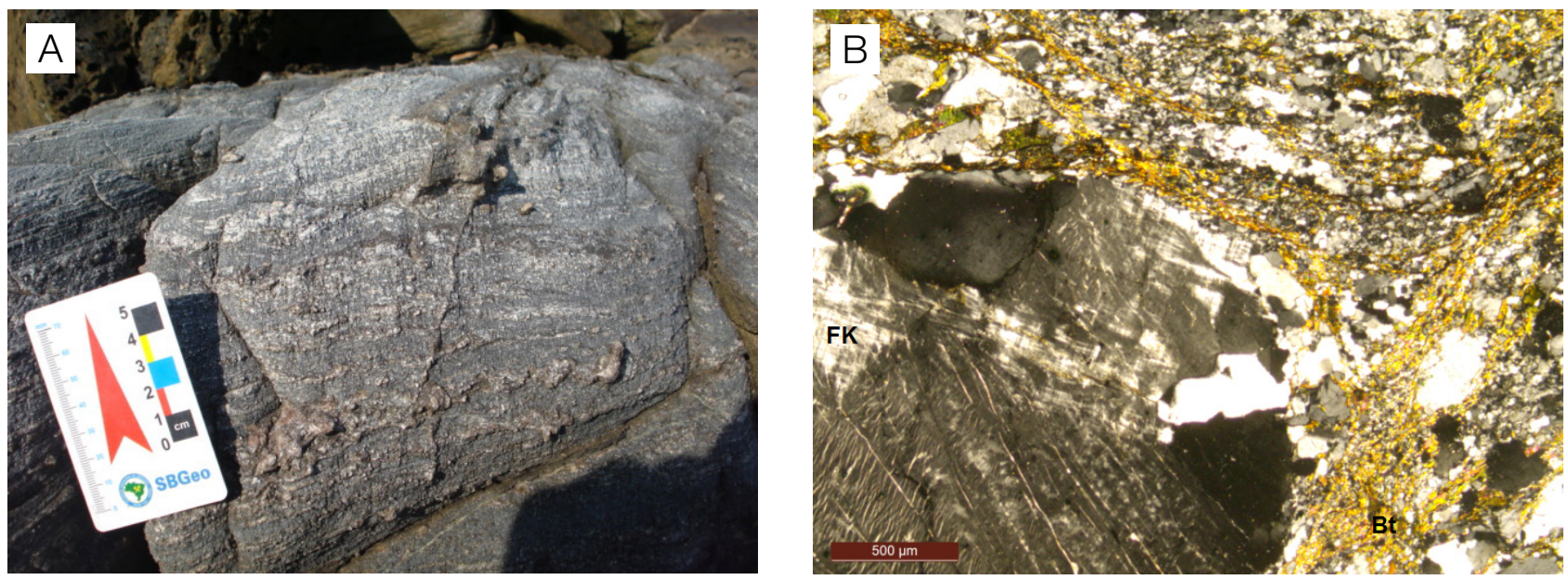

Figura 6. (A) Ortognaissemilonítico; (B) cristais finos de biotita anastomosados, estirados e contornando porfiroclasto (5 mm) de microclínio pertítico (luz com polarizadores cruzados). 
por anfibólio (80\%), labradorita (10\%), quartzo (5\%), biotita (5\%), minerais acessórios (opacos, zircão, titanita e apatita) e minerais secundários (epidoto, clorita esericita). Sua textura nematoblástica é definida pela orientação preferencial de anfibólio e plagioclásio, e sua estrutura, foliada.

Os cristais de anfibólio são médios, subédricos, prismáticos e orientados moderadamente segundo a direção da foliação Sn (Figura 7B). Microfraturas preenchidas por sericita e clorita podem ser descritas localmente.

A labradorita é fina, anédrica a subédrica, pode mostrar orientação preferencial fraca ou estar disposta de modo aleatório (Figura 7B). A labradorita pode apresentar extinção ondulante, kinkbands e microfraturas.

O quartzo é fino, anédrico, por vezes exibe extinção ondulante e não mostra orientação preferencial.

Os cristais de biotita são finos a médios, subédricos lamelares, e seus contatos são retilíneos e irregulares.

Os opacos são finos, de hábito anédrico granular, intersticiais e não apresentam orientação preferencial.

Os cristais de zircão são muito finos, de hábito anédrico granular e sem orientação preferencial, enquanto os de titanita, por sua vez, são finos, de hábito subédrico a anédrico granular e apresentam localmente fraca orientação preferencial.Os cristais de apatita são finos, de hábito anédrico a subédrico,ocorrem sem orientação preferencial e exibem contatos curvilíneos.

O epidoto é fino, de hábito anédrico granular e com contatos serrilhados e curvilíneos. Ocorre associado a fraturas nos cristais de labradorita. Já os cristais de clorita e sericita são finos, anédricos a subédricos e não mostram orientação preferencial.

\section{Enclaves metaultramáficos}

Os enclaves metaultramáficosocorrem em vários locais das ilhas dos Remédios e Feia, são de cor cinza-escuro e constituídos principalmente por augita e, subordinadamente, biotita e opacos. Eles têm tamanho centimétrico a métrico $(2,5 \mathrm{~m})$ e são ovalados, angulosos (Figura 8A), estirados e interdigitados, podendo ter formas boudinadas e sigmoidais. Estão dispostos paralelamente ou discordantes da foliação $\mathrm{Sn}$ da rocha hospedeira. A textura é granoblástica e a estrutura é maciça (Figura 8B).

Os cristais de augita são grossos, anédricos a subédricos e podem mostrar bordas parcialmente substituídas por biotita. A augita apresenta contato retilíneo, junções tríplices e arranjo granoblástico. Não são observadas evidências de deformação.

Os cristais de opacos são finos, de hábito anédrico granular a subédrico, com contatos retilíneos e serrilhados entre si e com os demais cristais da rocha.

\section{Enclaves gnáissicos}

Os enclaves gnáissicos apresentam formas ovaladas, sigmoidais e irregulares (Figura 9A) e comprimentos que variam de 3 a $25 \mathrm{~cm}$. Seu bandamento gnáissico (Figura 9B) é marcado pela alternância de níveis ricos em anfibólio e biotita, e de níveis quartzo-feldspáticos dispostos em arranjos nematoblásticos ou granulares orientados. Esse bandamento tem aspecto planar a levemente anastomosado e não possui continuidade física com a foliação do milonito hospedeiro. A dobra suave afeta a foliação gnáissica do enclave (Figura 9B), que, por isso, associa-se a uma fase de deformação anterior à formação dos milonitos. Esses enclaves gnáissicos têm comportamento similar ao de porfiroblastospré-tectônicos, ou seja, são macrólitos pretéritos em relação à fase de deformação milonítica (Dn).

\section{Estrutura}

As rochas das ilhas do Balneário Barra do Sul apresentam foliação protomilonítica ou milonítica $\mathrm{Sn}$, atribuída à fase $\mathrm{Dn}$,
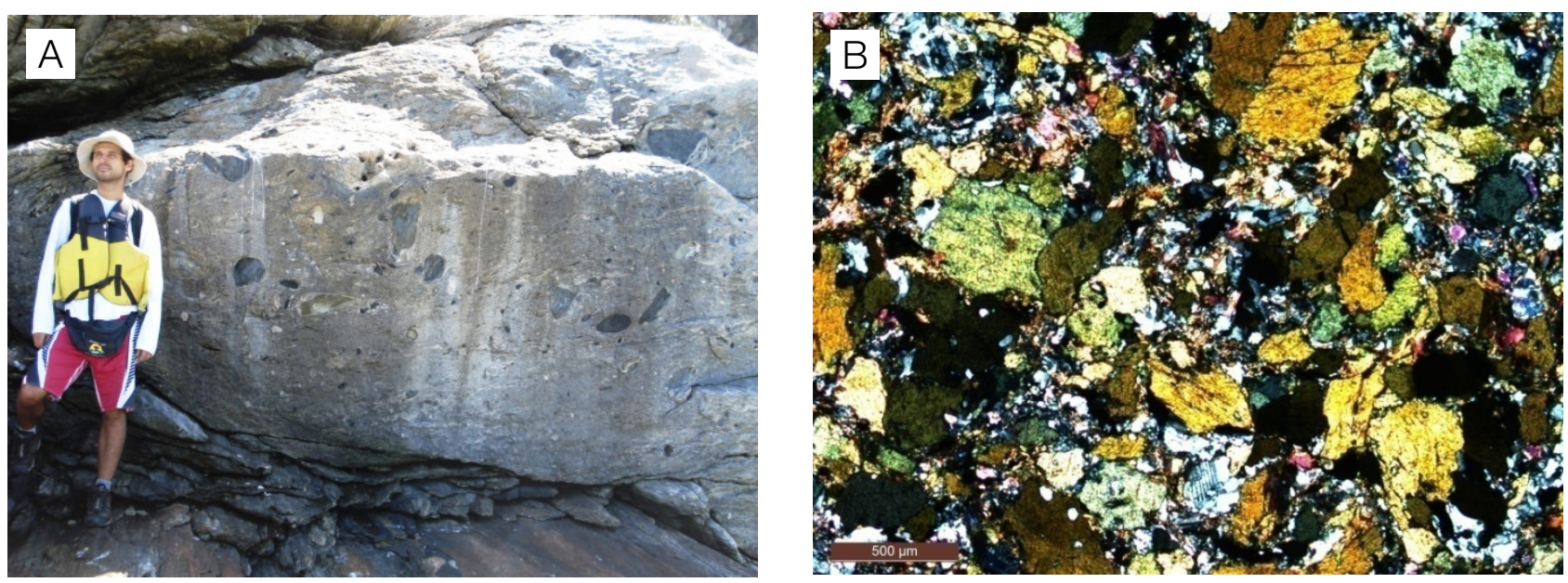

Figura 7. (A) Enclaves anfibolíticos arredondados em gnaisse milonítico; (B) fotomicrografia (luz com polarizadores cruzados) de enclave anfibolítico, no oeste da llha Feia. 
associada a zonas de cisalhamento geradas por cavalgamento. Caracteriza-se pela forte orientação preferencial de quartzo, microclínio, plagioclásio, anfibólio e biotita. Essa superfície é paralela a subparalela, localmente anastomosada e irregular e heterogênea, tem espaçamento milimétrico a centimétrico e é penetrativa nas escalas mesoscópica e microscópica. Apresenta direções em torno de N15E e mergulhos variáveis entre 20 e $40^{\circ}$ para NW (Figura 10A). A natureza dúctil é marcada pela recristalização dinâmica de feldspatos, pelo estiramento de minerais, pela presença de estruturas $\mathrm{S}-\mathrm{C}$ e dobras intrafoliares macroscópicas (Figura 10B) e pelo próprio desenvolvimento de milonitos em protólitos granitoides.

Lineações de estiramento mineral (Lan) são observadas sobre o plano da foliação Sn (N18E/35NW), com atitudes gerais $\mathrm{N} 212 / 6, \mathrm{~N} 295 / 30$ e N300/32, incluindo feldspatos estirados, augens de feldspato potássico ou plagioclásio, minerais micáceos orientados e ribbons de quartzo.
A foliação protomilonítica ou milonítica Sn é afetada por crenulação e dobras centimétricas a métricas, cilíndricas, assimétricas, inclinadas e heterogêneas. $\mathrm{O}$ ângulo interflancos é isoclinal a suave e a amplitude varia entre $5,0 \mathrm{~mm}$ a $1,0 \mathrm{~m}$. O comprimento de onda ocorre entre $3,0 \mathrm{~mm}$ a $1,5 \mathrm{~m}$. As dobras apresentam flancos com atitudes em torno de N15E/65NW, superfície axial de direção N31E/75NW e seus eixos (Lbn) de orientação N28/7 e N210/10.

Em algumas partes das ilhas dos Remédios e Feia a foliação Sn pode ser obliterada parcialmente por uma foliação posterior, de direções principais N31E/75NW e N25E/88NW, denominada $\mathrm{Sn}+1$ (Figura 11A) e atribuída à fase $\mathrm{Dn}+1$. Essa superfície é definida peloestiramento e pela recristalização de agregados quartzo-feldspáticos e pela reorientação de anfibólio. Possui caráter penetrativo e representa zona de cisalhamento transcorrente.
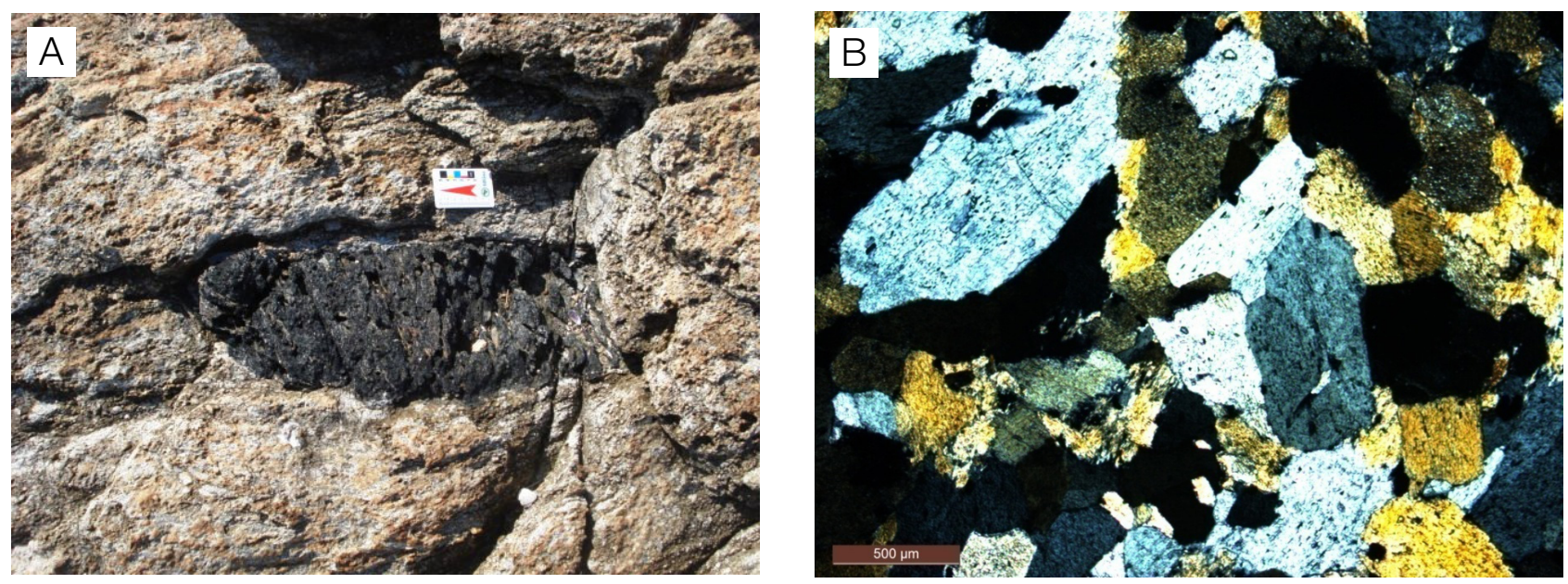

Figura 8. (A) Enclave metaultramáfico anguloso em meio ao ortognaissemilonítico da Ilha Feia; (B) fotomicrografia (luz com polarizadores cruzados) de enclaves metaultramáficos.
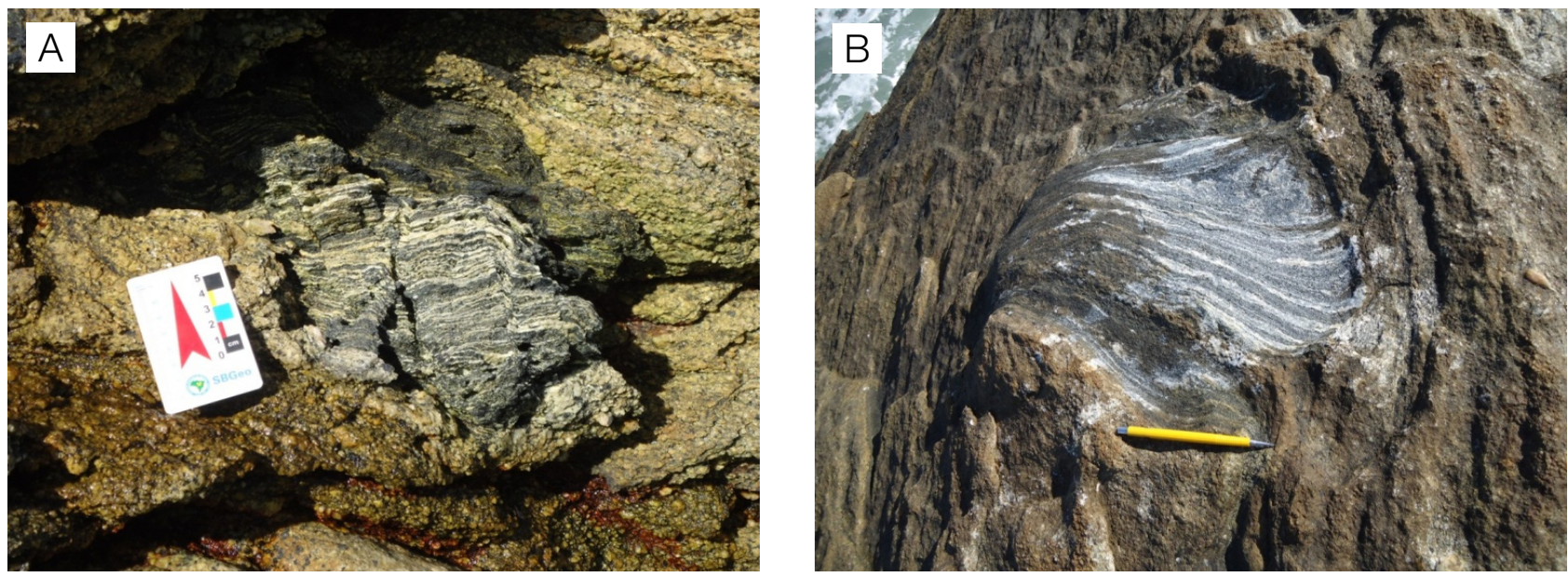

Figura 9. (A) Enclave gnáissico de formato irregular na porção oeste da llha Feia; (B) enclave gnáissico subarredondado caracterizado pelo bandamento milimétrico de níveis quartzo-feldspáticos e de minerais máficos. 
Essa foliação foi desenvolvida em regime dúctil-rúptil a dúctil, gerando protomilonitos e milonitos. As dobras geradas nesse evento podem ser identificadas em afloramento, têm dimensões variadas e caráter aberto (Figura 11B). $\mathrm{O}$ valor do mergulho dos eixos $(\mathrm{Lbn}+1)$ é baixo (entre 6 e $21^{\circ}$ ). Localmente, quando a superfície de alto ângulo de mergulho $\mathrm{Sn}+1$ torna-se fortemente desenvolvida, há estruturas linearizadas em forma de charuto, com dimensões centimétricas a decimétricas. A estrutura resulta da intersecção de superfícies ortogonais do tipo clivagem em lápis.

Análises de campo nas ilhas dos Remédios e Feia denotam que a foliação $\mathrm{Sn+lapresenta} \mathrm{estruturas} \mathrm{sigmoidais} \mathrm{(Figura} \mathrm{12A),}$ bandas de cisalhamento (Figura 12B) e enclaves assimétricos (Figuras 13A e 13B), indicando cinemática sinistral.

As rochas gnáissicas apresentam planos de fratura (Figura 14A) de caráter regularmente denso (espaçamento de $30 \mathrm{a}$
$100 \mathrm{~cm}$ ) a muito denso (espaçamento de 2 a $7 \mathrm{~cm}$ ). As fraturas são paralelas entre si ou localmente curvas, possuem geometria planar e persistência métrica (em torno de 0,5 a 1,5 m). Raramente ocorre alteração de suas paredes para óxido de ferro e muitas vezes não há preenchimento de minerais recristalizados em seus planos. Localmente pode ser observado o padrão conjugado (Figura 14B). As direções principais das fraturas são N65E/71NW, N75W/85NE, N80E/87SE e N80W/85SW.

\section{Geoquímica}

Os dados litogeoquímicos das rochas das ilhas do Balneário Barra do Sul e São Francisco do Sul nos laboratórios da Acme Analytical Laboratories Ltda (ACMELABS). Os elementos maiores e menores e alguns elementos-traço foram analisados por fluorescência de raios X. As concentrações
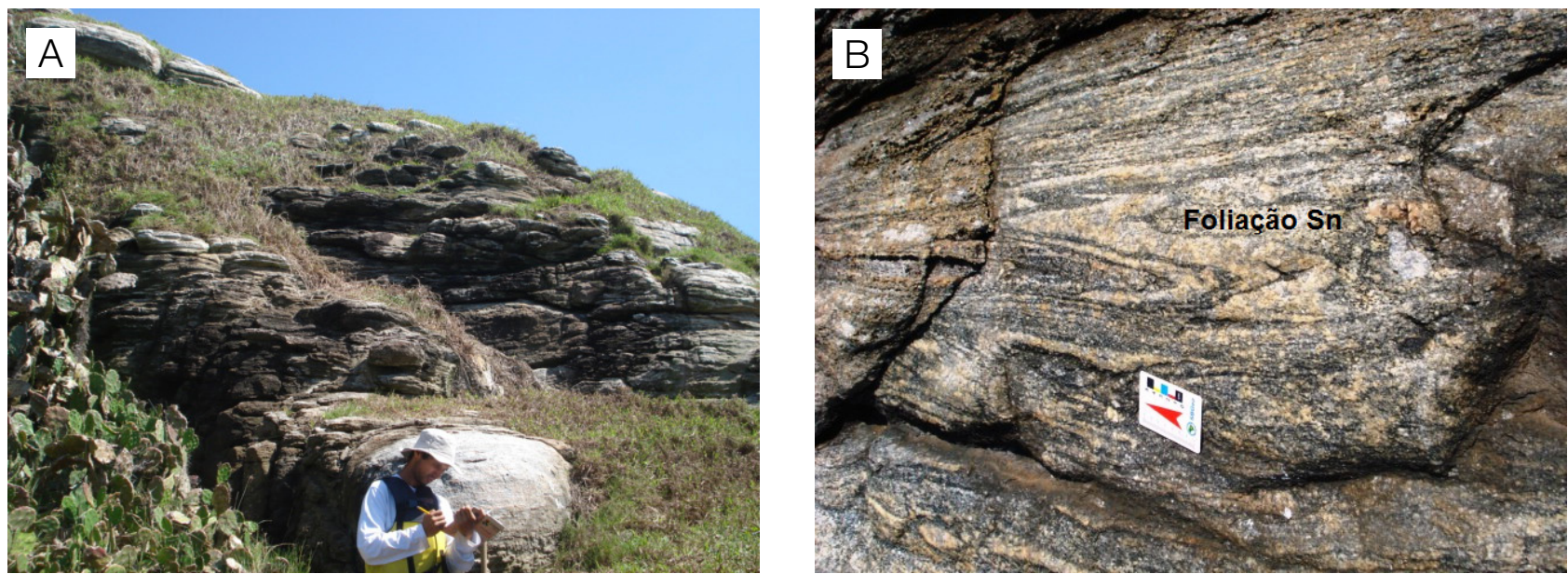

Figura 10. (A) Foliação milonítica Sn em ortognaisses com desenvolvimento de um bandamento composicional paralelo, localmente irregular e de espessura milimétrica; (B) ortognaissemilonítico da porção oeste da llha dos Remédios, exibindo dobras intrafoliaiscentimétricas.
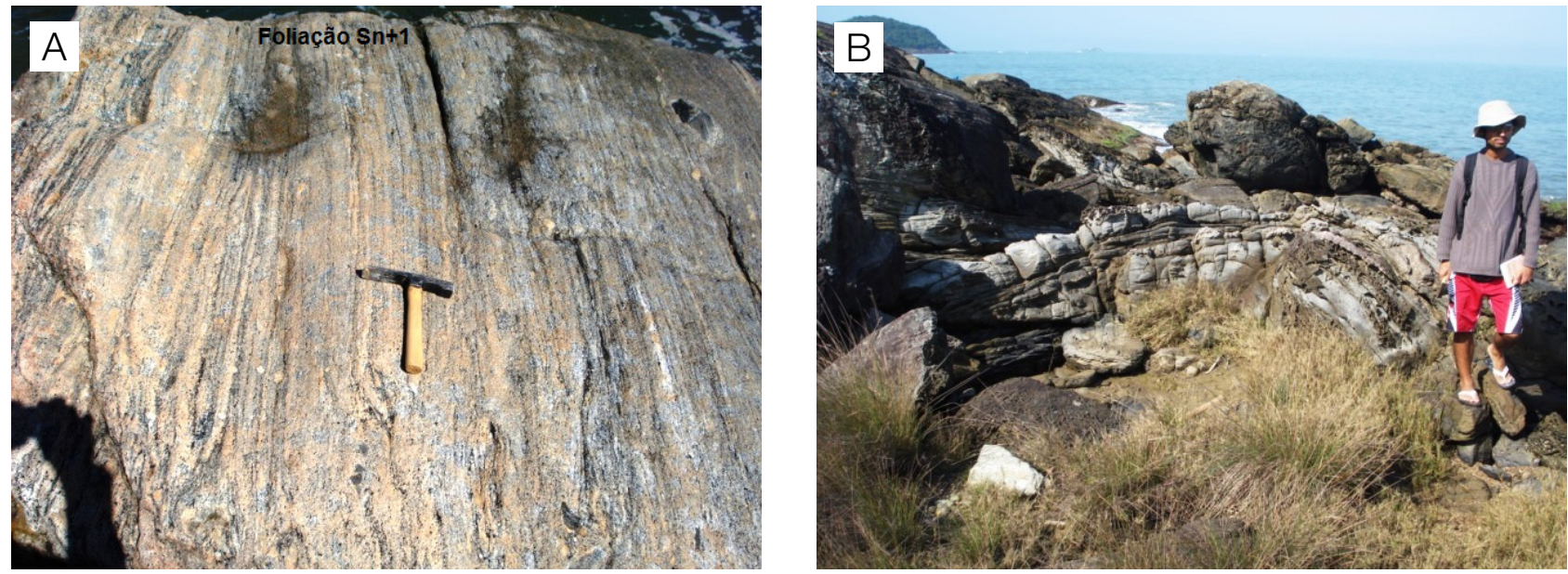

Figura 11. (A) Ortognaisseprotomilonítico da llha dos Remédios com foliação Sn+1 de caráter penetrativo, evidenciada pela orientação preferencial de minerais félsicos e máficos; (B) dobra aberta que afeta a foliação milonítica (Sn) com eixo Lbn+1 de baixo ângulo de caimento. 

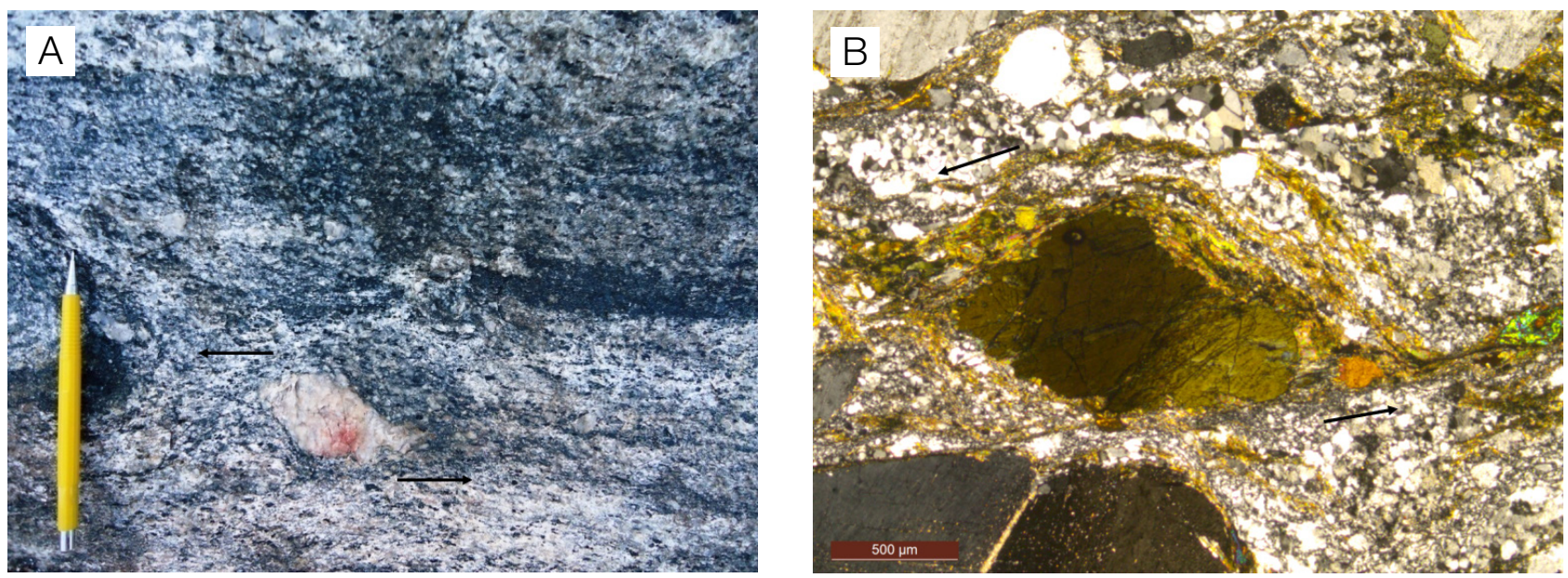

Figura 12. (A) Ortognaisseprotomilonítico com porfiroclastosigmoidal de feldspato potássico, na Ilha Feia (MTB - 34); (B) fotomicrografia do ortognaisseprotomilonítico (luz com polarizadores cruzados). Porfiroclasto tipo sigma de anfibólio com sombra de deformação assimétrica e foliações S-C indicativos de movimentação sinistral associada à foliação Sn+1.
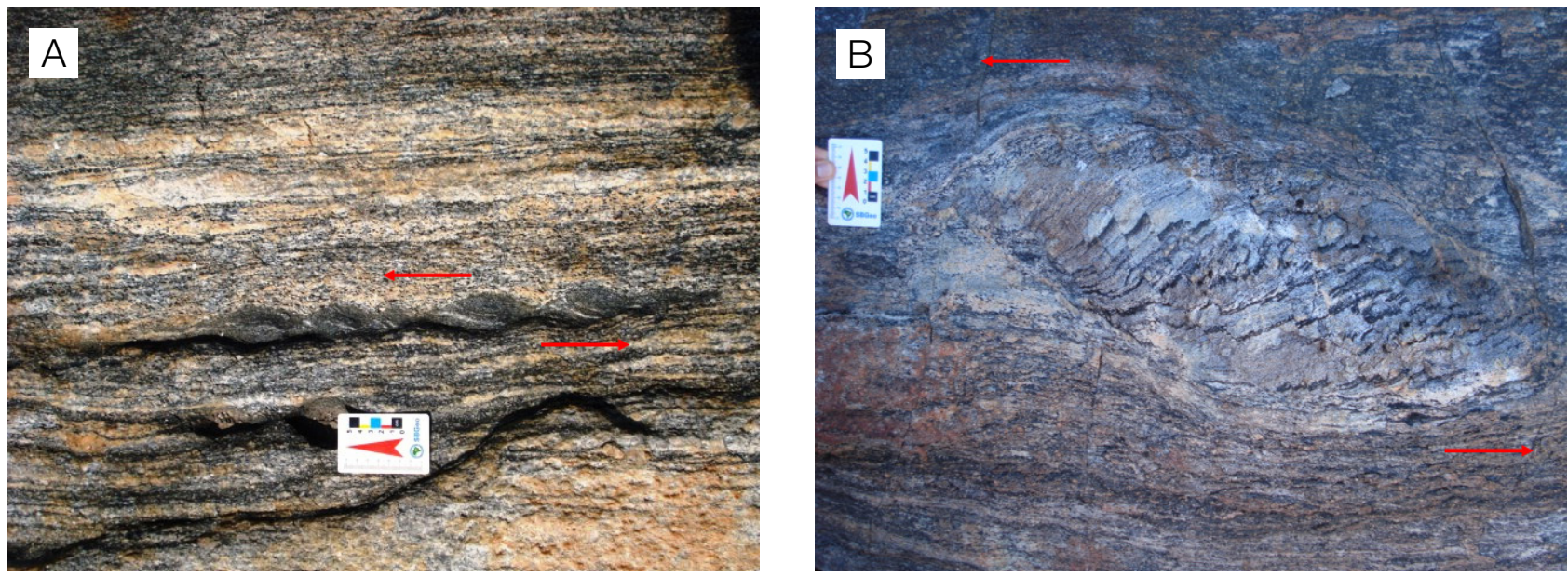

Figura 13. (A) Ortognaissemilonítico com enclaves metaultramáficossigmoidais indicativos de movimento sinistral para a foliação de alto ângulo $\mathrm{Sn+1}$, Ilha dos Remédios; (B) enclave gnáissico sigmoidal em ortognaisse com falhas antitéticas destrais. Ambas as feições indicam movimento sinistral.
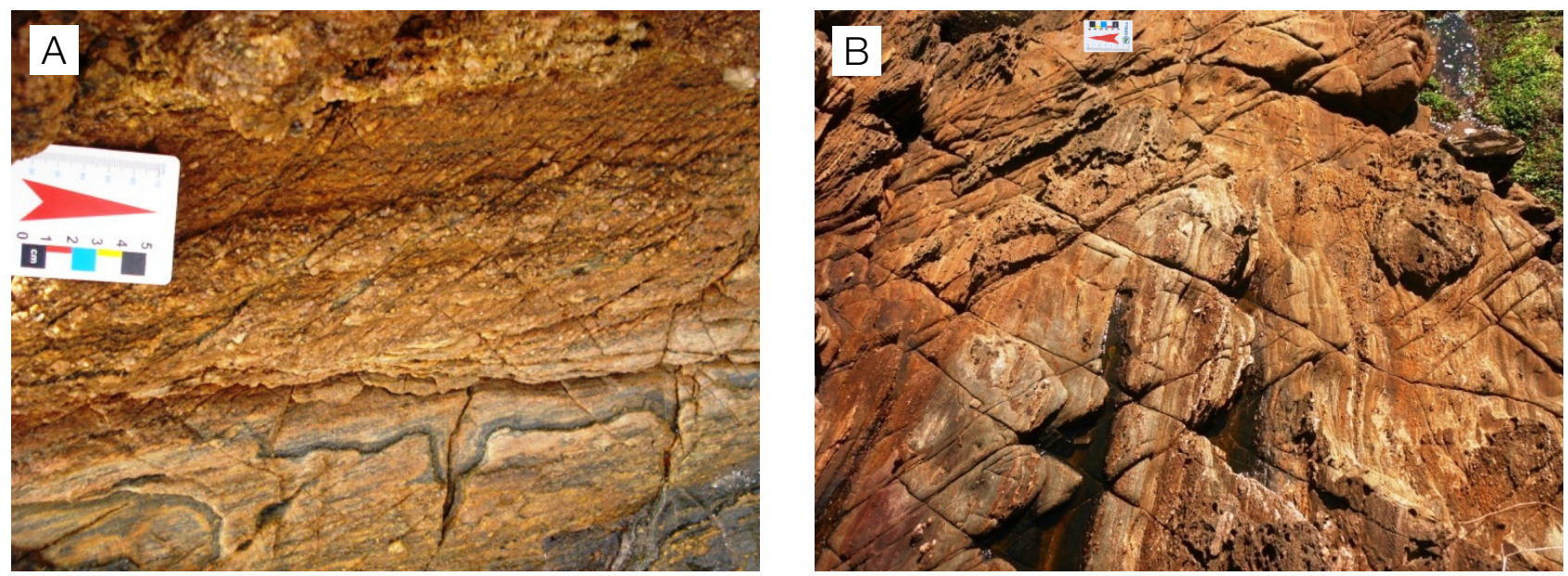

Figura 14. Ortognaisses miloníticos do oeste da llha dos Remédios. (A) fraturas centimétricas, de caráter muito denso (com espaçamento de $2 \mathrm{~cm}$ ), paralelas entre si e de geometria planar; (B) fraturas com padrão conjugado. 
de outros elementos-traço, incluindo os elementos terras raras (ETR), foram determinadas em espectometria de massa por plasma acoplado indutivamente (ICP-MS). Esses dados litogeoquímicos foram examinados conjuntamente, pois foram considerados pertencentes ao Complexo São Francisco do Sul devido a semelhanças petrográficas e estruturais. Foram analisadas cinco amostras de gnaisse granodiorítico (P-84a II, P-87, P-84b, MTB-34 A e P-69) e uma de gnaisse monzogranítico (P-83b) (Tabela 1). O conteúdo de $\mathrm{SiO}_{2}$ das rochas do Balneário Barra do Sul e São Francisco do Sul varia entre 60,25 e $70,21 \%$, com as amostras de granodiorito apresentando entre 66,21 e $68,62 \%$.

Os ortognaisses das ilhas do Balneário Barra do Sul e do município de São Francisco do Sul são cálcio-alcalinos a álcali-cálcicos (Figura 15A) e magnesianos (Figura 15B), conforme indicam os diagramas de Frost et al. (2001).

O padrão de ETR, normalizado pelo condrito de Nakamura (1974), mostra fracionamento moderado com ETR leves e valores menores de ETR pesados (Figura 16). Os ETR pesados apresentam padrão retilíneo quase horizontal ou ligeiramente inclinado, marcado pelas concentrações menores de ETR pesados. A amostra BP-83b (monzogranito) exibe moderada anomalia negativa de európio $(\mathrm{Eu})$, indicativa da retenção de plagioclásio na fonte ou da remoção deste mineral do líquido. Em consequência, seria possível supor que os processos de geração de magma e de diferenciação de líquidos teriam ocorrido, respectivamente, a altase a baixas pressões ( $c f$. Rollinson, 1993). Uma amostra apresenta pronunciada anomalia positiva de Eu, que reflete acúmulo do plagioclásio.

Os conteúdos de $\mathrm{Y}, \mathrm{Nb}$ e $\mathrm{Rb}$ são similares àqueles de granitos de arco vulcânico (Figuras 17A e 17B), quando lançados nos diagramas de Pearce et al. (1984).

\section{CONSIDERAÇÕES FINAIS}

A área mapeada constitui-se principalmente por ortognaisses protomiloníticos e miloníticos das ilhas do Balneário Barra do Sul (Remédios e Feia), as quais têm enclaves metaultramáficos, anfibolíticos e gnáissicos. Esses ortognaisses apresentam as mesmas características petrográficas e estruturais das rochas do Complexo São Francisco do Sul, descritas por Cury (2009).

A proximidade das ilhas do Balneário Barra do Sul a Barra Velha pressupõe que esses enclaves metaultramáficos sejam pertencentes ao corpo de metapiroxenitos desse município, considerados parte da Microplaca Luís Alves.

As rochas das ilhas do Balneário Barra do Sul foram afetadas por duas fases de deformação dúctil. A primeira (Dn) associa-se à tectônica de cavalgamentos, cuja vergência é para norte-nordeste (NNE); a segunda ( $\mathrm{Dn}+1)$, à tectônica transcorrente. A idade desses cavalgamentos é incerta; pode-se supor que esteja correlacionada às idades de 599 $\pm 5 \mathrm{Ma}$ e $594 \pm 3 \mathrm{Ma}$,obtidas pelo método U-Pb em monazita (Cury, 2009)em milonitos de zonas de cavalgamento do Terreno Paranaguá. A zona de cisalhamento transcorrente

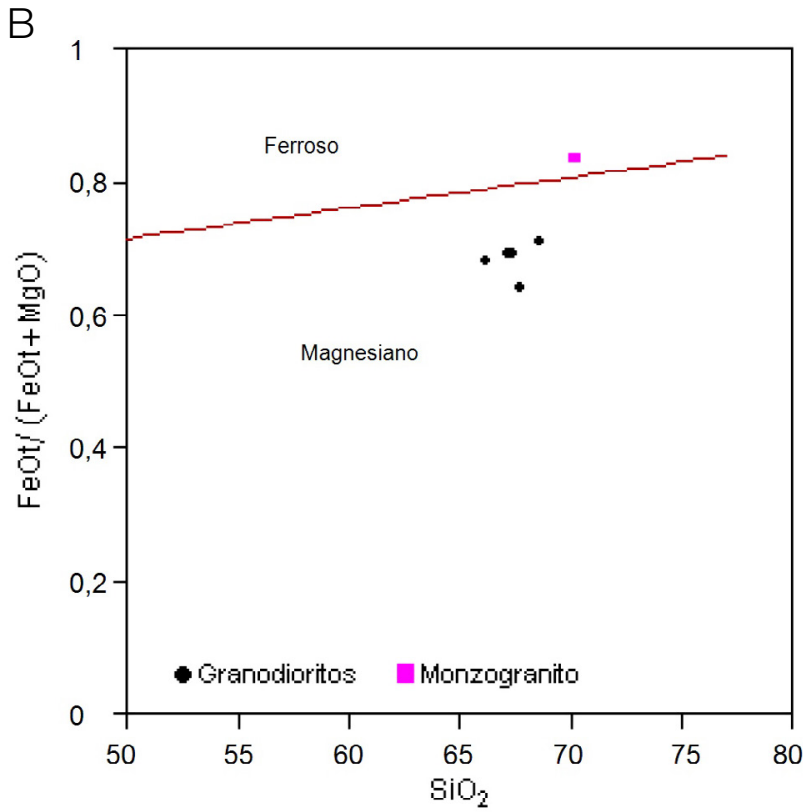

Figura 15. (A) Diagramas $\mathrm{SiO}_{2}$ versus $\mathrm{Na}_{2} \mathrm{O}+\mathrm{K}_{2} \mathrm{O}-\mathrm{CaO}$;(B) $\mathrm{SiO}_{2}$ versus FeOt/(FeOt+MgO) de Frost et al. (2001) com dados de ortognaisses das ilhas do Balneário Barra do Sul e do município de São Francisco do Sul. 
Tabela 1. Dados químicos dos ortognaisses das ilhas do Balneário Barra do Sul e de São Francisco do Sul (elementos maiores e menores, porcentagem em peso, elementos-traço em partes por milhão, perda ao fogo).

\begin{tabular}{|c|c|c|c|c|c|c|}
\hline Amostra & P-84a II & P-87 & $P-84 b$ & MTB- 34 A & P-69 & $P-83 b$ \\
\hline Composição do litotipo & Granodiorito & Granodiorito & Granodiorito & Granodiorito & Granodiorito & Monzogranito \\
\hline $\mathrm{SiO}_{2}$ & 66,21 & 67,14 & 67,4 & 67,71 & 68,62 & 70,21 \\
\hline $\mathrm{TiO}_{2}^{2}$ & 0,49 & 0,41 & 0,34 & 0,26 & 0,55 & 0,38 \\
\hline $\mathrm{Al}_{2} \mathrm{O}_{3}$ & 15,66 & 14,97 & 15,51 & 15,99 & 14,75 & 14,86 \\
\hline $\mathrm{Fe}_{2}^{2} \mathrm{O}_{3}^{3}$ & 4,19 & 3,34 & 3,07 & 2,56 & 4,65 & 2,97 \\
\hline $\mathrm{MnO}^{2}$ & 0,06 & 0,05 & 0,05 & 0,05 & 0,02 & 0,04 \\
\hline $\mathrm{MgO}$ & 1,77 & 1,33 & 1,23 & 1,30 & 1,71 & 0,53 \\
\hline $\mathrm{Cr}_{2} \mathrm{O}_{3}$ & & & & 0,010 & & \\
\hline $\mathrm{CaO}^{2}$ & 3,36 & 2,95 & 2,69 & 2,58 & 2,4 & 1,32 \\
\hline $\mathrm{Na}_{2} \mathrm{O}$ & 4,35 & 4,41 & 4,29 & 4,33 & 3,06 & 2,89 \\
\hline $\mathrm{K}_{2} \mathrm{O}^{2}$ & 2,53 & 3,21 & 3,96 & 3,77 & 3,04 & 6,00 \\
\hline $\mathrm{P}_{2}^{2} \mathrm{O}_{5}$ & 0,17 & 0,203 & 0,24 & 0,10 & 0,03 & 0,14 \\
\hline$P F^{2}$ & 0,41 & 0,0 & 0,14 & 1,0 & 0,10 & 0,04 \\
\hline $\mathrm{Ba}$ & 921,3 & 1427,7 & 2214,9 & 1677 & 694,6 & 1538,7 \\
\hline $\mathrm{Rb}$ & 81,4 & 74,2 & 73,7 & 98,7 & 114,3 & 176 \\
\hline $\mathrm{Sr}$ & 619,6 & 828,6 & 881,3 & 1003,3 & 250,1 & 294 \\
\hline $\mathrm{Zr}$ & 164,9 & 186,1 & 275,4 & 89,1 & 192,7 & 376,8 \\
\hline $\mathrm{Nb}$ & 14,8 & 17,4 & 19,9 & 5,1 & 26,6 & 15 \\
\hline $\mathrm{Ni}$ & 19,4 & 13,4 & 14 & 67 & 20,9 & 2,4 \\
\hline Co & 61,4 & 42,5 & 106,7 & 6,4 & 80 & 65,4 \\
\hline $\mathrm{Zn}$ & 46 & 61,8 & 35 & 27 & 59 & 43 \\
\hline $\mathrm{La}$ & 46,3 & 49,4 & 73,1 & 17,6 & 8,1 & 133,3 \\
\hline $\mathrm{Ce}$ & 87,5 & 70,4 & 136,8 & 36,2 & 12,4 & 223,1 \\
\hline $\operatorname{Pr}$ & 9,4 & 10,09 & 14,15 & 3,63 & 1,53 & 23,65 \\
\hline $\mathrm{Nd}$ & 34,1 & 36,8 & 47,2 & 12,1 & 5,4 & 77,9 \\
\hline $\mathrm{Sm}$ & 5,4 & 5,68 & 7,2 & 2,01 & 0,7 & 10,4 \\
\hline Eu & 1,22 & 1,47 & 1,56 & 0,70 & 1,53 & 1,49 \\
\hline $\mathrm{Gd}$ & 4,13 & 4,53 & 5,03 & 1,56 & 0,54 & 7,27 \\
\hline $\mathrm{Tb}$ & 0,56 & 0,57 & 0,7 & 0,21 & 0,11 & 0,85 \\
\hline Dy & 3,16 & 2,53 & 3,49 & 1,54 & 0,41 & 4,12 \\
\hline $\mathrm{Ho}$ & 0,63 & 0,48 & 0,63 & 0,23 & 0,11 & 0,68 \\
\hline $\mathrm{Er}$ & $\begin{array}{l}1,69 \\
\text {. }\end{array}$ & 1,21 & 1,61 & 0,53 & 0,27 & 2,13 \\
\hline $\mathrm{Tm}$ & 0,22 & 0,18 & 0,22 & 0,08 & 0,05 & 0,33 \\
\hline $\mathrm{Yb}$ & 1,42 & 1,18 & 1,59 & 0,66 & 0,27 & 2,12 \\
\hline Lu & 0,16 & 0,18 & 0,19 & 0,08 & $<1$ & 0,3 \\
\hline Y & 17,5 & 14,1 & 17,4 & 7,5 & 2,2 & 29,9 \\
\hline Cs & 3,9 & 1,5 & 0,7 & 1,6 & 5,6 & 5,2 \\
\hline Ta & 5,5 & 5,3 & 13,4 & 0,3 & 9,6 & 8,5 \\
\hline $\mathrm{Hf}$ & 4,7 & 5,1 & 7,7 & 2,5 & 5,2 & 10,7 \\
\hline $\mathrm{Be}$ & 3 & 2 & 2 & 4 & 2 & 2 \\
\hline Ga & 21 & 20,5 & 19,3 & 21,5 & 23,5 & 19,1 \\
\hline Sc & & & & 3 & & \\
\hline Sn & 1 & 2 & 1 & $<1$ & $<1$ & 2 \\
\hline Th & 13 & 12,9 & 16,1 & 8,6 & 1,3 & 18,3 \\
\hline U & 0,8 & 1,4 & 3,2 & 1,0 & 0,5 & 1,1 \\
\hline V & 60 & 45 & 42 & 43 & 65 & 28 \\
\hline W & 404,4 & 275,4 & 671,6 & $<0,5$ & 530,4 & 466,4 \\
\hline $\mathrm{Ag}$ & & & & $<0,1$ & & \\
\hline As & & & & $<0,5$ & & \\
\hline $\mathrm{Au}$ & & & & 1,8 & & \\
\hline $\mathrm{Bi}$ & & & & $<0,1$ & & \\
\hline $\mathrm{Cd}$ & & & & $<0,1$ & & \\
\hline $\mathrm{Hg}$ & & & & $<0,01$ & & \\
\hline Mo & 0,6 & & 1,2 & 5,6 & 1 & 0,9 \\
\hline $\mathrm{Cu}$ & 14,1 & 12,9 & 24,3 & 12,4 & 73,5 & 4,4 \\
\hline $\begin{array}{l}\mathrm{Ni} \\
\mathrm{Ph}\end{array}$ & & & & $\begin{array}{c}65 \\
153\end{array}$ & & 62 \\
\hline $\mathrm{Pb}$ & 9,6 & 34,7 & 21 & $\begin{array}{l}15,3 \\
<01\end{array}$ & 4,9 & 6,2 \\
\hline $\begin{array}{l}\mathrm{Sb} \\
\mathrm{Se}\end{array}$ & & & & $\begin{array}{l}<0,1 \\
<0,5\end{array}$ & & \\
\hline $\mathrm{Tl}$ & & & & 0,4 & & \\
\hline
\end{tabular}

P: ponto; MTB: Michelangelo Tissi Baldin. 
afeta granitos, provavelmente neoproterozoicos, que afloram em ilhas de Tamboretes, situadas mais ao norte (Baldin e Barros submetido para publicação). Esse fato permite sugerir que a tectônica de alto ângulo esteja associada às fases tardias da colagem do Terreno Paranaguá com a Microplaca Luís Alves. Os indicadores cinemáticos mostraram movimentação sinistral para a foliação $\mathrm{Sn}+1$.
A continuidade lateral na escala métrica das duas superfícies miloníticas, além das evidências de recristalização de feldspatos (Tullis, 1983; Scholz, 1988; Stippet al., 2002), indicam que as duas fases de deformação milonítica que afetaram as rochas das ilhas do Balneário Barra do Sul foram controladas por temperaturas superiores a $450^{\circ} \mathrm{C}$. As formas de limites de cristais de quartzo, subgrãos e novos grãos

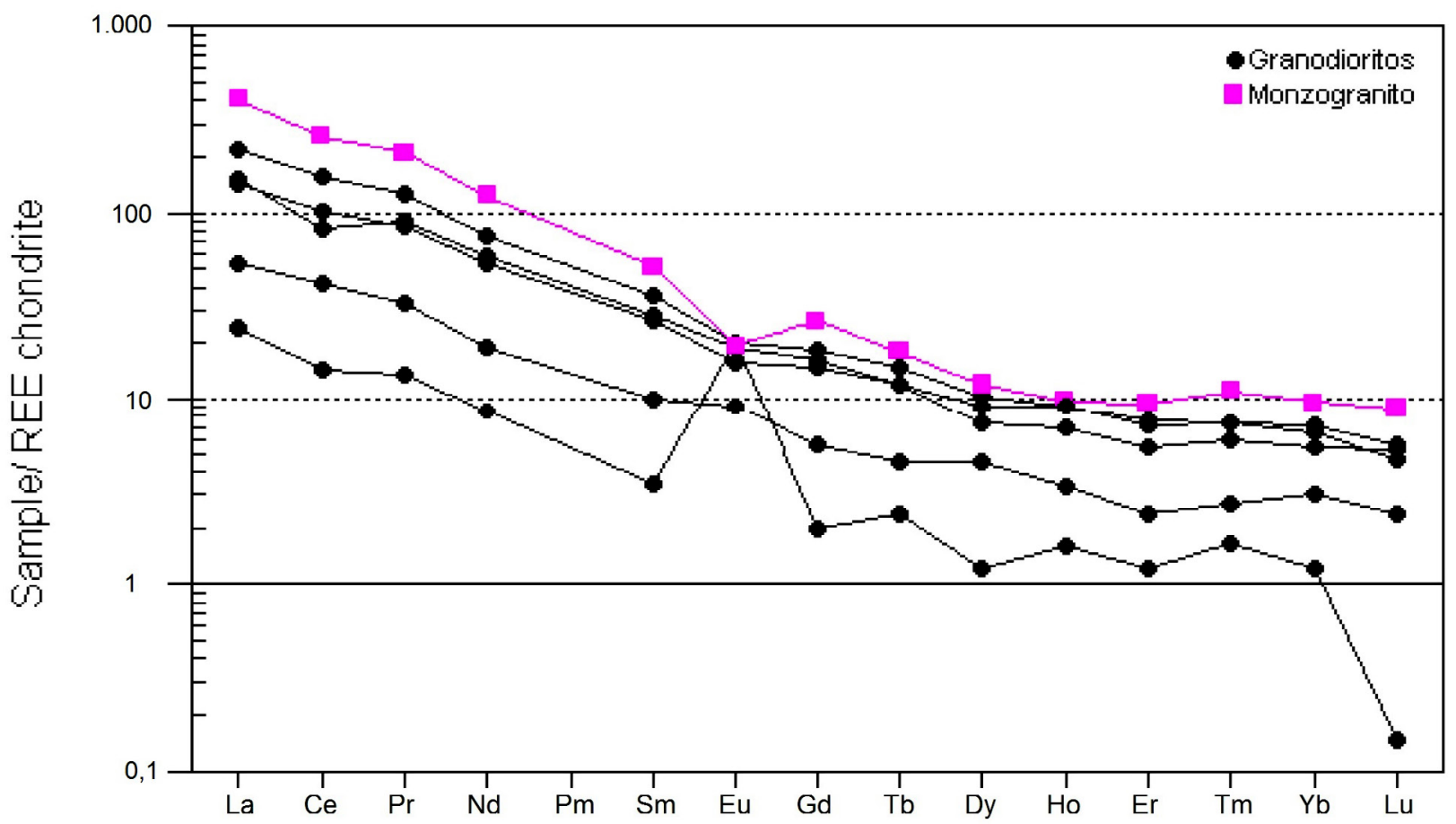

Figura 16. Diagrama de elementos-traço (normalizados pelo condrito de Nakamura, 1974) com dados de ortognaisses das ilhas do Balneário Barra do Sul e do município de São Francisco do Sul.

A

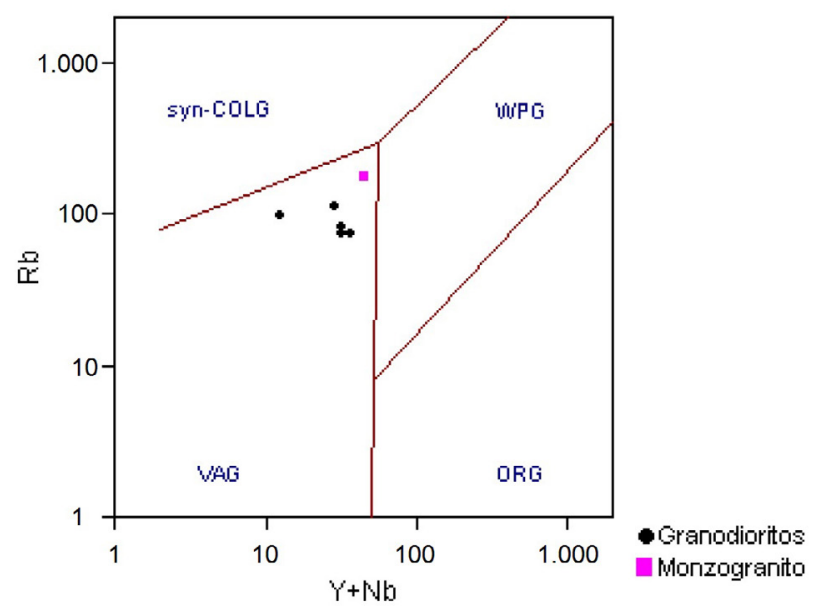

B

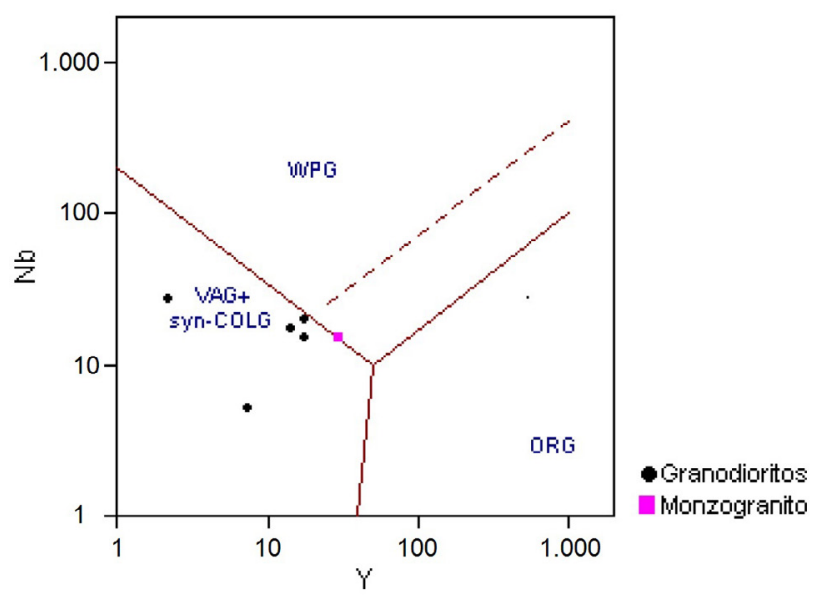

syn-COLG: granitos sin-colisionais; VAG: granitos de arco vulcânico; WPG: granitos de intraplaca; ORG: granitos orogênicos.

Figura 17. Diagramas de discriminação de ambientes tectônicos (Pearce et al., 1984). (A) diagrama $\mathrm{Y}+\mathrm{Nb}$ versus $\mathrm{Rb}$;(B) diagrama $\mathrm{Y}$ versus $\mathrm{Nb}$. 
sugerem a participação de mecanismos de rotação de subgrãos, os quais atuam preferencialmente a essas temperaturas (cf. Stippet al., 2002; Faleiros et al., 2010).

A despeito das duas fases de deformação dúctil que afetaram os protólitos graníticos das rochas das ilhas do Balneário Barra do Sul e do município de São Francisco do Sul, admite-se assinatura semelhante àquela de granitos do tipo I-Cordilheirano, nas proximidades de zonas de subducção. As rochas contrastam com esses granitos no caráter alto potássico e nas elevadas razões de elementos incompatíveis.

Segundo Pearce et al. (1984), os magmas gerados em subducção ou na cunha enriquecida do manto apresentam altas razões de LILE (íons litófilos de grande raio iônico)/HFSE (elementos de alta força de campo), ao contrário daqueles originados em ambientes intraplaca, enriquecidos em elementos HFSE. O caráter potássico dos gnaisses miloníticos do Balneário Barra do Sul e da Ilha de São Francisco do Sul poderia ser explicado pela contribuição de fontes de manto enriquecido com efetiva participação de um componente de crosta continental, seja em um contexto de zona de subducção ou tardi-colisional.

\section{AGRADECIMENTOS}

Os autores agradecem ao apoio institucional da Universidade Federal do Paraná (UFPR), do Departamento de Geologia e do Programa de Pós-Graduação em Geologia da UFPR. Michelangelo Tissi Baldin agradece à Coordenação de Aperfeiçoamento de Pessoal de Nível Superior (Capes) pela bolsa de mestrado. Carlos Eduardo de Mesquita Barros agradece ao Conselho de Desenvolvimento Científico Nacional (CNPq) pela bolsa de produtividade em pesquisa (Grants 306.021/2012-9 e 309.625/2015-7). Os autores agradecem aos editores pela oportunidade e aos revisores pelas valiosas contribuições, e são gratos à Sra. Anice Ambrósio de Mesquita Barros pela hospedagem no Balneário de Barra do Sul durante os trabalhos de campo.

\section{REFERÊNCIAS}

Basei, M. A. S. (1985). O Cinturão Dom Feliciano em Santa Catarina. Tese (Doutorado). São Paulo: Instituto de Geociências-USP.

Basei, M. A. S., Mcreath, I., Siga Junior, O. (1998). The Santa Catarina Granulite Complex of southern Brazil, a review. GondwanaResearch, 1, 383-391.

Basei, M. A. S., Siga Júnior, O., Machiavelli, A., Mancini, F. (1992). Evolução tectônica dos terrenos entre os Cinturões Ribeira e Dom Feliciano (PR - SC). Revista Brasileira de Geociencias,22(2), 216-221.
Basei, M.A.S., Siga Junior, O., Masquelin, H., Harara, O.M., Reis Neto, J.M., Preciozzi, P. (2000). The Dom Feliciano Belt of Brazil and Uruguay and its foreland domain, the Rio de La Plata Craton, framework, tectonic evolution and correlation with similar provinces of southwestern Africa. In: U. G. Cordani, E. J. Milani, A. ThomazFilho, D. A. Campo (Eds.). Tectonic Evolution of South American (31, 311-334). Rio de Janeiro: CPRM.

Cury, L. F. (2009). Geologia do Terreno Paranaguá. Tese (Doutorado). São Paulo: Instituto de Geociências-USP.

Departamento Nacional da Produção Mineral - DNPM. (1986). Mapa geológico do Estado de Santa Catarina. Escala 1:500.000. Florianópolis: CPRM.

Faleiros, F. M., Campanha, G. A. C., Bello, R. M. S., Fuzikawa, K. (2010). Quartz recrystallization regimes, $c$-axis texture transitions and fluid inclusion reequilibration in a prograde greenschist to amphibolite facies mylonite zone (Ribeira Shear Zone, SE Brazil). Tectonophysics, 485, 193-214.

Figueiredo, M. C. H., Basei, M. A. S., Mantovani, M. S. M., Fryer, B. J. (1991). O Complexo Granulítico de Santa Catarina, um arco insular arqueano? Boletim IG-USP. Publicação Especial, 9, 35-40.

Fornari, A. (1998). Geologia e metalogênese da porção meridional do Cráton Luís Alves-SC. Tese (Doutorado). Campinas: Instituto de Geociências-UNICAMP.

Frost, B. R., Barnes,C. G., Collins, W. J., Arculus, R. J., Ellis, D. J., Frost, C. D. (2001). A geochemical classification for granitic rocks. Journal of Petrology, 42(11), 2033-2048.

Harara, O.M.M. (2001). Mapeamento e investigação petrológica e geocronológica dos litotipos da região do Alto Rio Negro (PR-SC). Um exemplo de sucessivas e distintas atividades magmáticas durante o Neoproterozoico III. Tese (Doutorado). São Paulo: Instituto de Geociências-USP.

Hartmann, L.A., Santos J.O.S., Mcnaughton N.J., Vasconcellos M.A.Z., Silva L.C. (2000). SHRIMP dates recurrent granulite facies metamorphism in the Santa Catarina granulites, southern Brazil. Anais da Academia Brasileira de Ciências, 4, 559-572.

Hartmann, L.A., Silva, L.C., Orlandi Filho, V. (1979). O Complexo Granulítico de Santa Catarina. Descrição e implicações genéticas. Acta Geológica Leopoldensia, 3, 93-112.

Iglesias, C.M.F., Zerfass, H., Silva, M.A.S., Klein, C. (2011). Mapa Geológico da Folha Joinville - SG.22-Z-B. Escala 1:250.000. Brasília: CPRM. 
Instituto Brasileiro de Geografia e Estatística - IBGE. (1981). Folha Topográfica Araquari-SG-22-Z-B-II-4/MI-2870/4. Escala 1:50.000. Rio de Janeiro: IBGE.

Lopes, O.F. (1987). O granito sin-tectônico Cubatãozinho, petrogênese e evolução geológica. III Simpósio Sul-Brasileiro de Geologia (2, 481-490). Curitiba: SBG.

Minioli, B. (1972). Aspectos geológicos da região litorânea de Piçarras, Barra Velha, SC. Tese (Doutorado). São Paulo: Instituto de Geociências-USP.

Moore, A. C. (1970). Descriptive terminology for the textures of rocks in granulite facies terrains. Lithos, 3, 123-127.

Nakamura, N. (1974). Determination of REE, Ba, Fe, Mg, Na and $\mathrm{K}$ in carbonaceous and ordinary chondrites. Geochimica et Cosmochimica Acta, 38, 757-775.

Pearce, J. A., Harris, N. B. W., Tindle, A. G. (1984). Trace element discrimination diagrams for the tectonic interpretation of granitic rocks. Journal of Petrology, 25, 4, 956-983.

Pitcher, W. S. (1983). The nature and origin of granite. GrãBretanha: Blackie Academic \& Professional.
Rollinson, H. (1993). Using geochemical data: evaluation, presentation, interpretation. 352p. Grã Bretanha: Longman.

Scholz, C.H. (1988). The brittle-plastic transition and the depht of seismic faulting. Geologische Rundschau, 1, 319-328.

Sibson, R.H. (1977). Fault rocks and fault mechanisms. Journal of Geological Society of London, 133, 191-213.

Siga Junior, O. (1995). Domínios tectônicos do sudeste do Paraná enordeste de Santa Catarina, Geocronologia e Evolução Crustal. Tese (Doutorado). São Paulo: Instituto de Geociências-USP.

Siga Junior, O., Basei, M.A.S., Machiavelli, A. (1993). Evolução geotectônica da porção NE de Santa Catarina e SE do Paraná, com base em interpretações geocronológicas. Revista Brasileira de Geociências, 23(3), 215-223.

Stipp M., Stünitz H., Heilbronner, R., Schmid, S. M. (2002). The eastern Tonale fault zone: a "natural laboratory"for crystal plastic deformation of quartz over a temperature range from 250 to $700^{\circ}$ C. Journal of Structural Geology, 24(12), 1861-1884.

Tullis, J. (1983). Deformation of feldspars. In: P. H. Ribbe (ed.). Feldspars Minerals (297-323). Washington: Mineralogical Society of America. (Reviews in Mineralogy, 2). 